\title{
Quinacrine Hydrochloride
}

National Cancer Institute

\section{Source}

National Cancer Institute. Quinacrine Hydrochloride. NCI Thesaurus. Code C67059.

The dihydrochloride salt of the 9-aminoacridine derivative quinacrine with potential antineoplastic and antiparasitic activities. Quinacrine may inhibit the transcription and activity of both basal and inducible nuclear factor-kappaB (NF-kappaB), which may result in the induction of tumor suppressor p53 transcription, the restoration of p53-dependent apoptotic pathways, and tumor cell apoptosis. Continuous NF-kappaB signaling, present in many tumors and in chronic inflammatory processes, promotes the expression of antiapoptotic proteins and cytokines while downregulating the expression of proapoptotic proteins, such as p53. 